\title{
Effects of sunlight on bacterial growth in lakes of different humic content
}

\author{
Måns J. Lindell*, H. Wilhelm Granéli, Lars J. Tranvik \\ Dept of Ecology/Limnology, Ecology Building, S-223 62 Lund, Sweden
}

\begin{abstract}
We investigated the bacterial response to sunlight in 5 oligotrophic lakes of different humic content [dissolved organic carbon (DOC) 3.9 to $19 \mathrm{mg} \mathrm{l}^{-1}$, water color 0 to $140 \mathrm{mg}$ platinum $(\mathrm{Pt}$ ) $\mathrm{I}^{-1}$ ] in southern Sweden. Lake water including free-living, heterotrophic bacteria was exposed in situ in quartz tubes at 5 depths $(0 \mathrm{~m}$ to Secchi depth) from sunrise to sunset during July. In sunlight exposed surface water, ${ }^{3} \mathrm{H}$-leucine uptake, measured immediately after retrieval of the tubes at dusk, was inhibited in all lakes by 23 to $85 \%$ (most severely in clear water) compared to dark controls. Inhibition was detectable at $2 \mathrm{~m}$ in the clearest lake while in the most humic lake there was no effect below $0.2 \mathrm{~m}$. Depth integrated loss of bacterial production in light tubes compared to dark ones decreased with increasing DOC content, ranging from $23 \%$ (clear lake) to $1-4 \%$ (humic lakes). To study the indirect effects of solar light on bacteria, due to phototransformation of dissolved organic matter (DOM), $0.2 \mu \mathrm{m}$ filtered lake water was exposed from sunrise to sunset at 4 depths $(0,0.2,0.65$ and $2 \mathrm{~m})$ and then inoculated with bacteria, which were allowed to grow in darkness. At stationary phase the abundance and cell volume increased by 23 to $99 \%$ and 20 to $123 \%$, respectively, related to dark exposed controls, resulting in increases in biomass between 83 and $175 \%$. The depth integrated light mediated increase in bacterial carrying capacity (23 to $34 \%$ ) showed no relation to DOC content. Direct inhibition of growth by sunlight, and indirect stimulation of growth from increased availability of DOM, were detectable to depths greater than detectable UV-B penetration, indicating that wavelengths $>320 \mathrm{~nm}$ affect bacterial growth. We suggest that during exposure to daylight, bacteria are mainly negatively affected by UV light, especially in clear waters, but a simultaneous stimulation due to phototransformation of recalcitrant DOM into more available forms occurs. Time spent by cells and DOM in light exposed zones during mixing determines the relative importance of these counteracting processes.
\end{abstract}

KEY WORDS: Light DOC $\cdot$ UV-B $\cdot$ Photochemical $\cdot$ Bacteria $\cdot$ Pelagic

\section{INTRODUCTION}

Aquatic organisms living near the surface are exposed to solar light, often with decreased metabolism as a consequence (Karentz et al. 1994). The harmful effects are thought to be mainly due to UV radiation. The effects of UV radiation on aquatic systems is a function of incoming irradiation, adaptations to light such as shielding by protective pigments, and absorbance of substances in the water such as dissolved organic matter (DOM) (Helbling et al. 1992, Scully \& Lean 1994). Waters rich in DOM (humic matter) absorb UV radiation efficiently (Scully \& Lean 1994) and may act as a protective filter for aquatic organisms.

•E-mail: mans.lindell@limnol.lu.se
Negative effects of sunlight in marine environments have been reported for almost every group of organisms. Suttle \& Chen (1992) reported UV radiation as the most important factor for virus decay in the upper $200 \mathrm{~m}$ of the ocean. Several studies on bacteria demonstrate a negative metabolic impact down to significant depths (Bailey et al. 1983, Sieracki \& Sieburth 1986, Herndl et al. 1993). Light exposure of flagellates retards motility (Ekelund 1993), and primary production may decrease in response to UV radiation (Karentz et al. 1994). Thus, it is reasonable to assume that aquatic ecosystems will react with reduced overall productivity to increased UV exposure.

A. few studies have focused on the potential indirect stimulatory effects of phototransformation of recalcitrant DOM to more labile DOM (Kieber et al. 1989, 
Lindell et al. 1995). In oligotrophic humic waters, bacterioplankton rely partly on allochthonous organic matter as an energy source (Hessen 1985, Tranvik 1988). DOM may be photochemically transformed by cleavage of large molecules into smaller units (Armstrong et al. 1966, Il'In \& Orlov 1973). Recent reports have focused on the ecological consequences of DOM photolysis (Mopper \& Stahovec 1986, Mopper et al. 1991). The cleavage products may be consumed by bacteria as rapidly as they are produced (Kieber et al. 1989). Thus, sunlight, and especially UV-B radiation, may increase the lability of DOM and thereby enhance bacterial growth (Lindell et al. 1995).

Reports of UV effects on organisms and DOM in marine waters, especially in Antarctic waters, appear trequently in the Literature (ci. review by Ǩarentz et ai. 1994) with accompanying data on UV light extinction. The importance of UV effects in lakes has largely been neglected since lakes generally contain more DOM, resulting in great extinction of light. Also few lakes are situated under the Antarctic ozone hole. However, as lakes are generally less than $10 \mathrm{~m}$ deep (Wetzel 1990), the exposed layer may constitute a significant part of the water column. Only a few studies have focused on factors that determine UV extinction and UV effects on bacteria in lakes (Scully \& Lean 1994).

In this study, we demonstrate that bacterial production in lakes is negatively affected by sunlight. The extent and depth distribution of the inhibition depends on the humic content of the lake. On the other hand, DOM is phototransformed into labile forms, which increases the availability of bacterial substrates for growth

\section{MATERIAL AND METHODS}

Experiments were done from July 6 to August 3, 1994 , in 5 oligotrophic lakes close to the limnological field station at Aneboda (the Einar Naumann Laboratory, $57^{\circ} 07^{\prime} \mathrm{N}, 14^{\circ} 34^{\prime} \mathrm{E}$, ca $30 \mathrm{~km}$ to the north of Växjö in southern Sweden. The lakes represent a spectrum from clear to polyhumic (Table 1).

Two studies were performed: (1) direct response of bacterial production to sunlight as a function of depth of exposure (measurements of bacterial production after light exposure of the natural bacterioplankton); and (2) indirect positive effects on bacteria due to phototransformation of DOM [exposure of bacteria-free (0.2 $\mu \mathrm{m}$ filtered) lake water, followed by inoculation with a bacterial assemblage].

The epilimnion was sampled over the deepest portion of each lake using a $2 \mathrm{~m}$ long, $50 \mathrm{~mm}$ inner diameter Plexiglass tube, which was emptied into a $10 \mathrm{l}$ polyethylene container Within $1 \mathrm{~h}$, water was filtered through $142 \mathrm{~mm} \mathrm{~A}$ /E glass fibre filters (Gelman Science, nominal pore size $1.2 \mu \mathrm{m}$ ) and $47 \mathrm{~mm}$ Whatman GF/F filters (nominal pore size $0.8 \mathrm{~mm}$ ) into a $1.0 \mathrm{l}$ Pyrex bottle using a peristaltic pump. With this procedure, we removed all eucaryotes but retained most of the bacteria in the water. The filtrate was allowed to grow overnight in darkness at room temperature, then siphoned into sterile quartz (light exposure) or borosilicate (dark exposure) test tubes (diameter $40 \mathrm{~mm}$, length $200 \mathrm{~mm}$, volume $190 \mathrm{ml}$ ), which were sealed with silicon stoppers. Triplicate light and dark samples were incubated at 5 depths between $0 \mathrm{~m}$ and the Secchi depth.

To siudy line effects of photochemical transformation of DOM, the water was also passed through $142 \mathrm{~mm}$ $0.2 \mu \mathrm{m}$ pore size membrane filters (Gelman) and finally through sterile $0.2 \mu \mathrm{m}$ pore size VacuCaps ${ }^{T M}$ (Gelman) directly into sterile quartz (light exposure) or borosilicate (dark exposure) test tubes (same dimensions as above), sealed with silicon stoppers. Before use, the tubes and stoppers were washed in diluted (1:10) hydrochloric acid, rinsed in Milli-Q water and autoclaved. Darkened samples were wrapped with aluminium foil. Quadruplicate samples were incubated at 4 different depths down to $2.0 \mathrm{~m}$

Tubes were fixed with rubber bands horizontally on supports made from coated (white) steel wiring. The supports were suspended from wooden frames, with the tubes hanging in a horizontal position. Tubes were incubated in each lake from sunrise to sunset (ca 04:00 to $22: 00 \mathrm{~h}$ ).

Around noon, Secchi depth and radiation profiles were taken at the deepest part of each lake. A portion of the water from the lakes was used for measurements of $\mathrm{pH}$ and color.

Bacterial production. Bacterial production was measured according to the leucine method as described by Smith \& Azam (1992), employing centrifugation instead of filtration. Triplicate samples $(1.7 \mathrm{ml})$ were incubated in the dark at room temperature

Table 1. Characteristics of the investigated lakes. Depth of epilimnion was determined by Ruttner sampler with thermometer as the depth at which temperature began to decrease rapidly. nd: not determined

\begin{tabular}{|lcrccc|}
\hline Lake & $\begin{array}{c}\text { Water color } \\
\left(\mathrm{mg} \mathrm{Pt} \mathrm{l}^{-1}\right)\end{array}$ & $\begin{array}{c}\text { DOC } \\
\left(\mathrm{mg} \mathrm{l}^{-1}\right)\end{array}$ & pH & $\begin{array}{c}\text { Secchı depth } \\
(\mathrm{m})\end{array}$ & $\begin{array}{c}\text { Epilımnion } \\
(\mathrm{m})\end{array}$ \\
\hline Klintsjön & 0 & 3.9 & 5.4 & 7.6 & 7.5 \\
Fiolen & 10 & 7.0 & 7.3 & 5.5 & 7.0 \\
Stråken & 45 & 9.7 & 7.2 & 2.9 & nd \\
Skärshultssjön & 80 & 11.2 & 5.7 & 1.9 & 4 \\
Lindhuitsgöl & 140 & 19.4 & 7.5 & 1.5 & 1.5 \\
\hline
\end{tabular}


$\left(25^{\circ} \mathrm{C}\right)$ with $\mathrm{L}-\left(4,5-{ }^{3} \mathrm{H}\right)$-leucine (Amersham ${ }^{\mathrm{TM}}$, TRK 510,140 to $160 \mathrm{Ci} \mathrm{mmol}^{-1}, 1.0 \mathrm{mCi} \mathrm{ml}^{-1}$ ). Blanks (TCA added before isotope) were run in parallel. We used $10 \mathrm{nM}$ final concentration of ${ }^{3} \mathrm{H}$-leucine in the 3 oligohumic lakes, while in the 2 most humic lakes (Skärshultsjön and Lindhultsgöl), the rate of isotope uptake was saturated first at $100 \mathrm{nM}$ leucine. Hence, $15 \mathrm{nM}$ of labelled leucine was added to unlabelled substrate to achieve a final concentration of $100 \mathrm{nM}$. Dark incubations were normally started within 60 min of sample collection.

Incubations $(60 \mathrm{~min})$ were terminated by adding $90 \mu \mathrm{l}$ of $100 \%$ (w/v) TCA (5\% final concentration). Samples were shaken for a few minutes and then centrifuged at $14000 \times g$ for $15 \mathrm{~min}$. The supernatant was aspirated and the remaining pellet resuspended and subsequently washed with $5 \%$ TCA and $80 \%$ ethanol. After final centrifugation/aspiration, $1.0 \mathrm{ml}$ of liquid scintillation cocktail (Quicksafe A, Zinsser Analytic ${ }^{\top M}$ ) was added. The radioactivity was determined by LSC. Quenching was corrected by using external standards.

Bacterial numbers and biomass. After in situ exposure, $18 \mathrm{ml}$ of the content of the tubes was transferred into sterile $20 \mathrm{ml}$ glass scintillation vials and inoculated with $10 \%(\mathrm{v} / \mathrm{v})$ Whatman GF/F filtered lake water from the same lake. The inoculum had been precultured for $24 \mathrm{~h}$ in darkness and at room temperature. To avoid limitation of bacterial growth by inorganic phosphorus, we enriched the water in each vial with inorganic $\mathrm{P}$ (final concentration $1 \mu \mathrm{M} \mathrm{KH} \mathrm{KH}_{2} \mathrm{PO}_{4}$ ). In the sampled lakes, this procedure generally resulted in cultures limited by organic carbon (L. J. Tranvik et al. unpubl.).

After inoculation, bacteria were allowed to grow for 70 to $90 \mathrm{~h}$ in order to reach stationary phase, after which replicates were killed at intervals of 8 to $10 \mathrm{~h}$ using $0.2 \mu \mathrm{m}$ filtered and buffered formaldehyde ( $2 \%$ final concentration). Bacterial abundance was determined by epifluorescence microscopy after staining with DAPI (Porter \& Feig 1980). At least 250 cells and 10 fields were counted for each sample. Each sample was photographed on Kodak T-Max 400 film. The negatives were projected onto a screen and the contour of approximately 100 cells of 3 to 5 negatives per sample were drawn on a paper $(-400$ cells per depth and exposure). Drawings were scanned into a computer file and the length $(l)$ and width $(w)$ were calculated using an image analysis program. Cell volumes $(V)$ were calculated from the formula $V=4 / 3 \pi r^{3}+\left[\pi r^{2}(l-2 r)\right]$, which approximates each cell as a cylinder with a hemisphere at either end $[\mathrm{r}=$ radius $(=w / 2)]$.

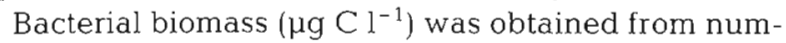
bers multiplied with the geometric mean of cell volumes and by using a carbon-to-cell conversion factor

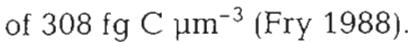

Light. Light attenuation was measured at noon with an IL $1400 \mathrm{~A}$ radiometer (International Light ${ }^{\mathrm{rM}}$ ) connected to 3 different broad-band sensors (photosynthetic active radiation, PAR: 400 to $750 \mathrm{~nm}_{i}$ UV-A: 320 to $400 \mathrm{~nm}$; UV-B: 280 to $320 \mathrm{~nm}$ ). The UV-B sensor has peak response signal at $313 \mathrm{~nm}$ and weaker response signal for the energy within 315 to $320 \mathrm{~nm}$, which is unfortunate, as most of the energy of UV-B is within this range. Thus, the UV-B attenuation reported here is primarily based on the shorter UV-B wavelengths, i.e. $<315 \mathrm{~nm}$.

Because UV-B radiation was attenuated within the upper centimetres in the more humic lakes, water was poured into a wide bucket with the sensor fixed on the bottom, a technique also used by Scully \& Lean (1994). Water level was increased in mm intervals. In this way the effects of waves and movements of the boat were avoided. Vertical attenuation coefficients $\left(K_{d}\right)$ were calculated for each wavelength band by fitting straight lines to ln-transformed values of radiation over depth. Radiation was also measured daily with intervals of 0.5 to $1 \mathrm{~h}$ for each wavelength band (PAR, UV-A and UV-B).

Dissolved organic carbon (DOC). Samples for DOC were either analysed directly or stored frozen in acid rinsed, precombusted $\left(500^{\circ} \mathrm{C}\right.$, overnight) glass vials with Teflon-lined screw caps. Organic $\mathrm{C}$ of the rethawed samples was analysed by Pt-catalysed hightemperature combustion using a Shimadzu ${ }^{\top M}$ TOC5000 total carbon analyser with an autosampler. Standard solutions were prepared from Milli- $Q$ water and hydrogen phthalate (pro analysi quality) at repre-

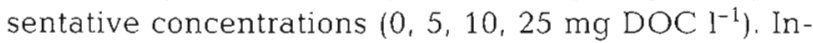
organic $\mathrm{C}$ was purged for $5 \mathrm{~min}$ from acidified samples ( $\mathrm{pH} \sim 2, \mathrm{HCl}$ ) with $\mathrm{CO}_{2}$-free air. Before analysis, thawed samples were sonicated in an ultrasonic bath to destroy any flocculates of DOM that might have formed due to freezing and thawing. For each analysis, 3 to 5 replicate injections were made on the carbon analyser, resulting in a coefficient of variation of $<2 \%$.

\section{RESULTS}

The investigated lakes comprise a natural humic gradient with Secchi depths varying between 1.5 and $7.6 \mathrm{~m}$, color between 0 and $140 \mathrm{mg} \mathrm{Pt} \mathrm{l}^{-1}, \mathrm{pH}$ between 5.4 and 7.5, DOC between 3.9 and $19 \mathrm{mg} \mathrm{l}^{-1}$ (Table 1). $\mathrm{pH}$ was not related to DOC, color or Secchi depth (linear correlation, $\mathrm{p}>0.05$ ).

\section{Direct inhibitory effects}

At the surface, loss of bacterial production in light samples varied from $23 \%$ (humic) to $85 \%$ (clear) com- 
pared to dark controls (Fig. 1) but showed no relation to DOC content (Fig. 2A). In the 2 clearest lakes, inhibition was still significant at $2 \mathrm{~m}$ depth (Mann-Whitney $U$-test, $\mathrm{p}=0.05$ ) but in the more humic lakes, inhibition was restricted to only 0 to $0.65 \mathrm{~m}$ (Fig. 1). Dark controls differed significantly (Kruskal-Wallis test, $\mathrm{p}<$ 0.05 ) within profiles, with lower production in deeper layers (at Secchi depth), coincident with the lower temperature during in situ incubation.

Depth integrated loss of bacterial production down to the Secchi depth was negatively related to DOC content (Fig. 2B) ranging from $23 \%$ in the clearest lake to $1-4 \%$ of dark values in the 2 humic lakes.

\section{İndìrect stimuiaiion ef̂́ecis}

Bacterial biomass in samples exposed in Strảken showed no significant differences between light and

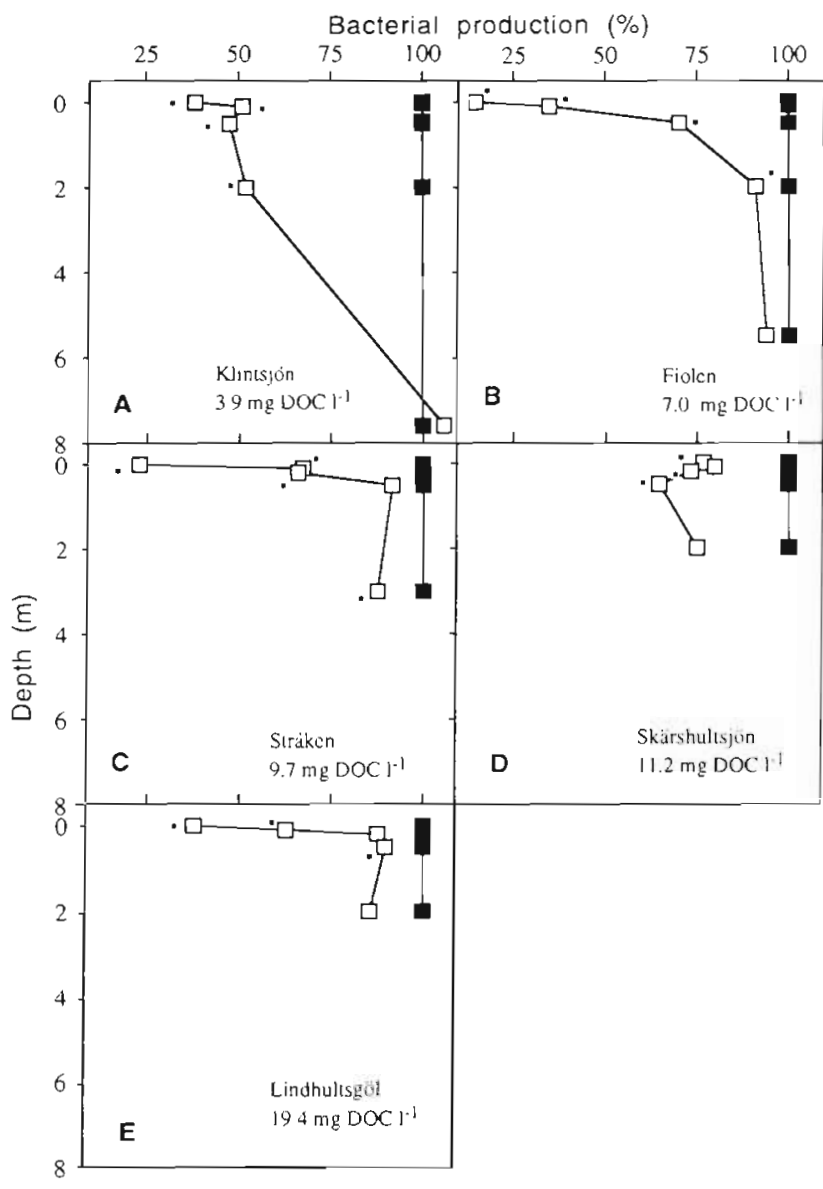

Fig. 1 Depth profiles of bacterial production in samples preincubated from dawn to dusk in transparent quartz tubes ( $\square$ ) as a percentage of production in dark controls ( $\square$ ). "Significantly ( $p<0.05$, Mann-Whitney $U$-test) lower production in light dark samples at any depth (Fig. 3C). We have excluded resuits from Stråken from further conclusions isee 'Discussion').

Dark controls generally did not differ between depths in any of the lakes, indicating no thermal influence on bacterial DOM availability.

At the surface, bacterial biomass in stationary phase cultures was higher in light exposed samples from all lakes (184 to $276 \%$ ) than in dark controls (Mann-Whitney, $\mathrm{p}<0.05$ ) (Fig. 3). Increases in biomass were due to increases in both cell number and cell volume. The increase in bacterial biomass at the surface was positively related to DOC content (linear regression, $p<0.05$ ), most pronounced in the polyhumic lakes (276 and $237 \%$ in Skärshultsjön and Lindhuitsgöi, respectively, compared io dark cuniuvis) (Fig. 4A). However, the bacterial carbon produced per unit of initial DOC (bacterial C:initial DOC ratio) in the water was not related to DOC content (Fig. 4A).

The depth integrated increase in bacterial carrying capacity was most pronounced in the most humic lake, Lindhultsgöl (Fig. 4B). Increases in biomass were detected deeper (i.e. below $0.2 \mathrm{~m}$ ) in clear lakes than in humic lakes (Fig. 3), and the depth integrated relative increase in bacterial biomass was higher in clear lakes compared to humic lakes (Fig. 4B).

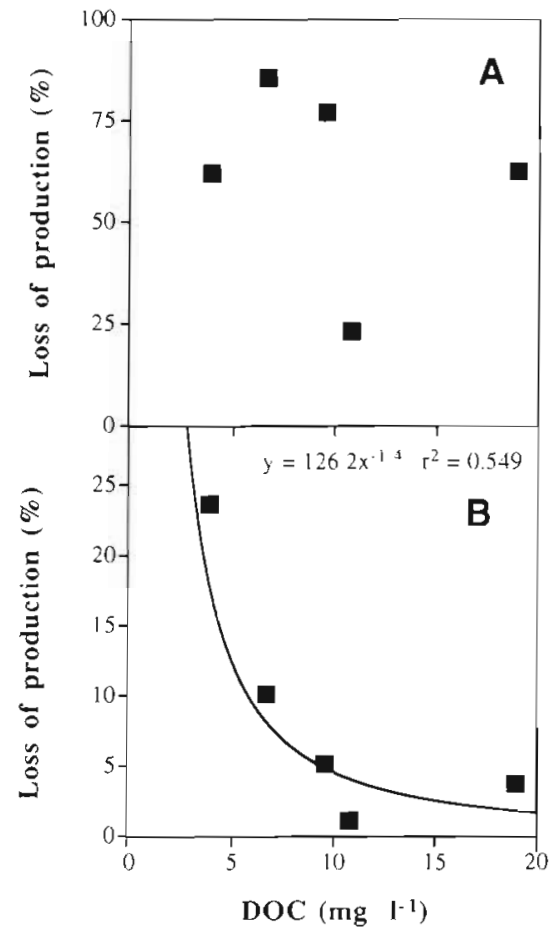

Fig. 2. Loss of bacterial production in relation to DOC content (A) at surface and (B) depth integrated 

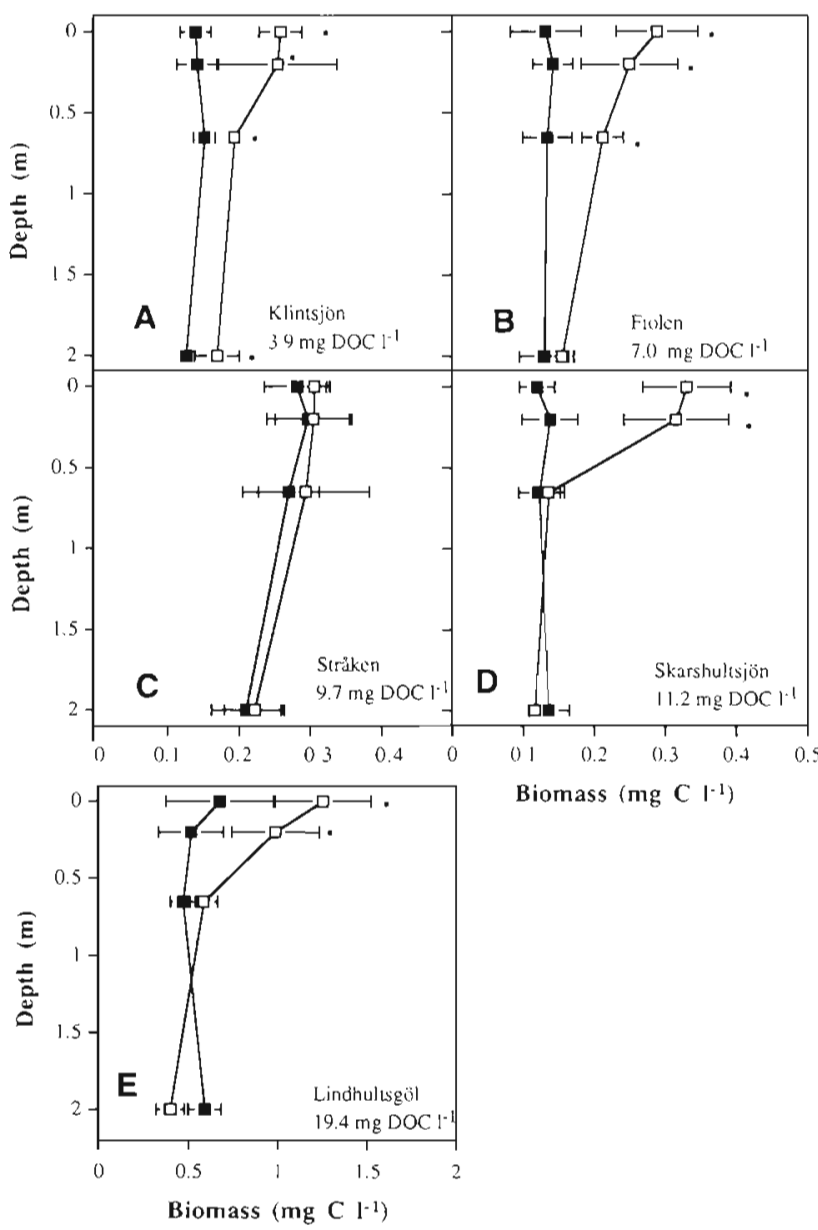

Biomass ( $\mathrm{mg} \mathrm{C}^{-1}$ )

Fig. 3. Bacterial carrying capacity after exposure of sterile lake water at different depths. ( $\square$ ) Light exposed samples and (ם) dark exposed samples. 'Significantly ( $p<0.05$, MannWhitney $U$-test) higher carrying capacity in light

\section{Light}

The slopes for all linear regression lines of ln-transformed light values versus depth were significantly different $(p<0.05)$ from zero except for the attenuation of UV-A in Lindhultsgöl. In some cases UV-A and UV$B$ values deviated from exponential curves (especially in the more humic lakes), possibly due to selective absorbance in the upper part of the water column of the shorter wavelengths.

Vertical attenuation coefficients $\left(K_{\mathrm{d}}\right)$ for PAR ranged from 0.44 to $2.56 \mathrm{~m}^{-1}$, UV-A from 1.24 to $3.89 \mathrm{~m}^{-1}$ and UV-B from 4.53 to $150 \mathrm{~m}^{-1}$ (Table 2). Vertical attenuation coefficients of all 3 wavelength bands were positively correlated to DOC content (linear regression, $\mathrm{p}<$ 0.05). The depths at which $1 \%$ of surface light remained ranged for PAR from 1.7 to $11 \mathrm{~m}$, for UV-A from 0.8 to $3.5 \mathrm{~m}$ and for UV-B from 0.03 to $1.1 \mathrm{~m}$, with high attenuation in the humic lakes.
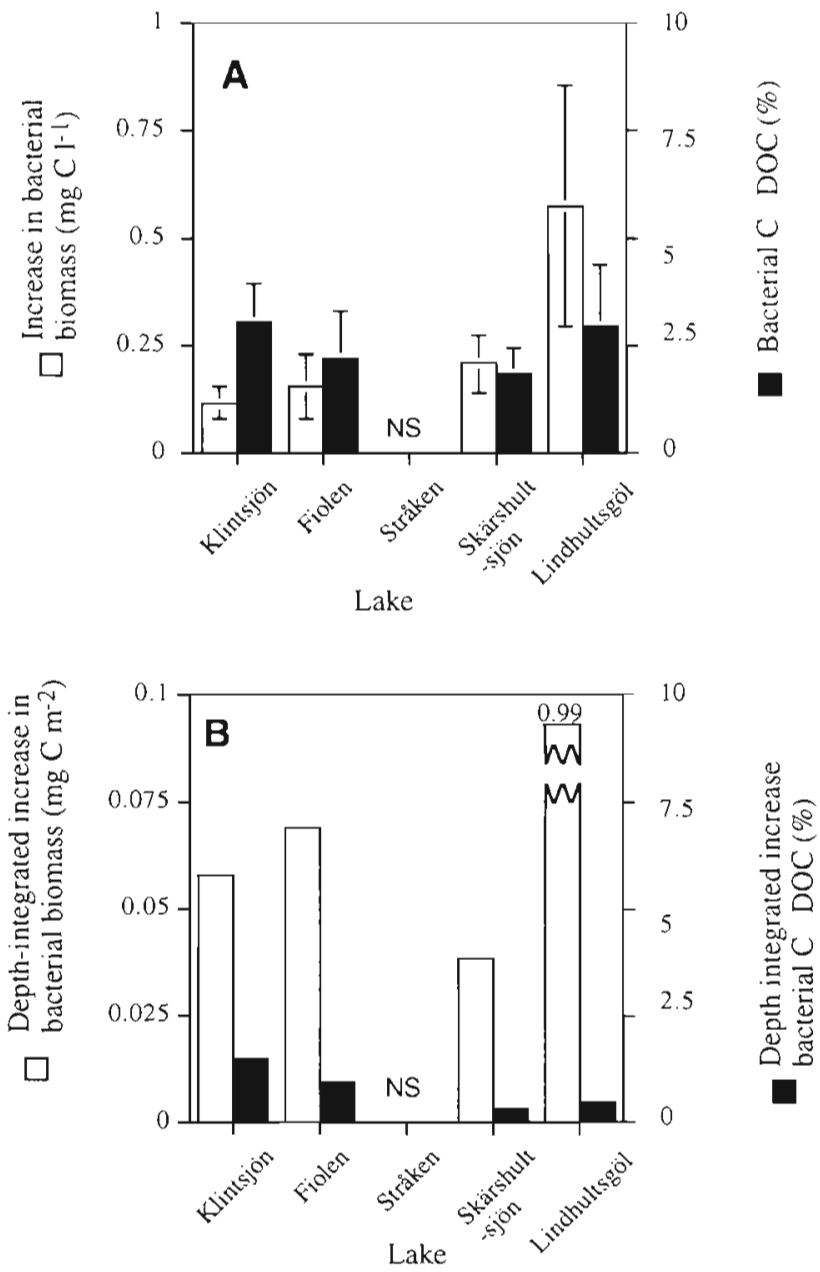

Fig. 4. Increase in bacterial biomass (calculated as biomass at stationary phase in light minus dark values) at (A) surface and (B) depth integrated. Unfilled bars indicate the increase expressed as $\mathrm{mg} \mathrm{C} \mathrm{m}{ }^{-2}$, while filled bars indicate the increase of bacterial biomass in relation to initial DOC concentration. Error bars in (A) are standard deviations of replicates $(n=4)$. NS: not shown (see text)

Table 2. Vertical attenuation coefficients (based on ln-transformed radiation values) and depth at $1 \%$ surface light of the investigated lakes

\begin{tabular}{|lccc|}
\hline Lake & PAR & UV-A & UV-B \\
\hline Klintsjön & 0.44 & 1.24 & 4.53 \\
& $(11 \mathrm{~m})$ & $(3.5 \mathrm{~m})$ & $(1.1 \mathrm{~m})$ \\
Fiolen & 0.55 & 1.91 & 22.4 \\
& $(8.2 \mathrm{~m})$ & $(2.1 \mathrm{~m})$ & $(0.22 \mathrm{~m})$ \\
Stråken & 1.27 & 1.68 & 34.3 \\
& $(3.6 \mathrm{~m})$ & $(1.7 \mathrm{~m})$ & $(0.14 \mathrm{~m})$ \\
Skärshultsjön & 2.10 & 1.36 & 69.3 \\
& $(2.0 \mathrm{~m})$ & $(1.9 \mathrm{~m})$ & $(0.07 \mathrm{~m})$ \\
Lindhultsgöl & 2.56 & 3.89 & 150.1 \\
& $(1.7 \mathrm{~m})$ & $(0.8 \mathrm{~m})$ & $(0.03 \mathrm{~m})$ \\
& & & \\
\hline
\end{tabular}




\section{Dissolved organic carbon}

There were no significant differences in DOC between light and dark samples after exposure at any depth or lake.

\section{DISCUSSION}

This study demonstrates that bacteria in lakes may be both directly inhibited and indirectly stimulated by solar radiation.

Inhibition of bacterial production occurred deeper than penetration of UV-B as measured with our radiometer. In the clearest lake, Klintsjön, inhibition was detected down to $2 m$, but in the nost huñic lake, Lindhultsgöl, it was only detected down to $0.2 \mathrm{~m}$, although UV-B was only measurable down to $0.7 \mathrm{~m}$ and to $2 \mathrm{~cm}$, respectively. This suggests that wavelengths longer than $320 \mathrm{~nm}$ also have an impact. Sieracki \& Sieburth (1986) showed that growth of marine bacterioplankton was significantly inhibited by UV-A (320 to $400 \mathrm{~nm}$ ) at a depth at which only $16 \%$ of incident UV-A irradiation remained. They reported that this fraction of incident UV-A is detectable in coastal waters at $12 \mathrm{~m}$ and off-shore at $55 \mathrm{~m}$. In the lakes examined in our study, we measured differences between bacterial production in light and dark exposed samples down to depths of 1 to $8 \%$ of incident UV-A. The differences between our results and those of Sieracki \& Sieburth (1986) may be due to different radiometers. In any case, relatively low intensities of UV-A may negatively affect bacterial growth, and even PAR may have negative effects on bacterioplankton.

Inhibition of bacterial production may result from secondary photoeffects on DOM, e.g. due to photochemical production of inhibitory substances like radicals, e.g. superoxide and hydrogen peroxide (Cooper et al. 1989). Photochemical inactivation of ectoenzymes (Müller-Niklas et al. 1995) may also decrease the overall bacterial metabolism during sunny days in lakes. However, we suggest that bacterioplankton may benefit from photolysis of DOM, due to conversion of DOM into forms with increased availability as bacterial substrates. Bacteria in surface exposed samples increased in numbers and size compared to bacteria in dark exposed samples, resulting in approximately a doubling in biomass in samples from all lakes but Stråken. Bacterial biomass in Stråken showed no difference between light and dark at any depth in contrast to the other 4 lakes. We have no explanation for the deviation. Among possible sources of errors is lack of inorganic nutrients (i.e. no nutrients added by mistake) or that sunlight had no effects on the DOM present in Straken. The latter is less likely, as in a parallel study we have measured significant photooxidation of DOM into inorganic carbon in the same water under the same conditions (Granéli et al. 1996).

In a laboratory study, bacterial cell numbers and cell volumes increased following photochemical transformation of DOM (Lindell et al. 1995). Lindell et al. (1995) noted that after a few hours of exposure to UV, the reactive parts of DOM were probably photooxidized as no further increase in bacterial biomass was measured in samples that received higher light doses. Similarly, Kieber et al. (1989) reported a daily photochemical production of pyruvate molecules in marine waters and a subsequent bacterial utilisation of pyruvate. Thus, it is likely that a few hours at the surface is enough to significantly increase the pool of bacterial substrates. Howeven, as bacterioplankion al the surface may be metabolically inhibited, thus not capable of utilizing the enriched pool of potential substrate, the stimulation must take part either after mixing to greater depths or at night. Possibly, large cell volumes may be caused by photogeneration of substances, remaining in the water even after exposure, that inhibit cell division. However, a more likely explanation is the photoproduction of bacterial substrate that generates large cells.

The potentially stimulating effects on bacteria of photochemical transformation of DOM into labile forms (Kieber et al. 1989, Lindell et al. 1995) counteracts to some extent the physiological inhibition by light. While close to surface, bacteria are inhibited by sunlight, but deeper and during the night, they may use the enriched pool of substrate. In our study, inhibition of growth affected a layer of 0.2 to $2 \mathrm{~m}$ depending on humic content. Thus, bacteria are more negatively affected in clear than in humic waters (Figs. 1 \& 2B). At the same time, the potential depth integrated stimulation is greater in clear lakes than in humic lakes (due to greater active depth) (Figs. $3 \& 48$ ). Incubation at fixed depths during one day may have exaggerated the photochemical effects.

We conclude that 2 processes, with opposing effects, influence bacterioplankton in lakes. Inhibition of bacterial production by UV light may be due to direct cellular damage and possibly photoproduction of inhibitory substances. Simultaneously, bacterioplankton may be stimulated by the photochemical transformation of high molecular weight DOM into smaller units, being more available to bacteria. Our experiment included only DOM, viruses, free enzymes and the bacterial fraction of the plankton community. More complicated secondary photochemical effects on bacterioplankton and DOM, e.g. photoinactivation of viruses and ectoenzymes, were not considered.

In clear lakes (Secchi depth 5 to $10 \mathrm{~m}$ ), photolysis of DOM (Granéli et al. 1996) causes increase in bacterial 
carrying capacity to depths of about 2 to $3 \mathrm{~m}$, while in humic lakes (Secchi depth 0 to $2 \mathrm{~m}$ ) the same effects are restricted to 0 to $0.5 \mathrm{~m}$. Longer wavelengths than those of UV-B, i.e. UV-A and possibly also PAR, may be more ecologically relevant as these wavelengths penetrate deeper than UV-B. The balance between stimulation and inhibition probably depends on the vertical mixing, the effects of which remain to be studied.

Acknowledgements. This study was supported by grants from the Swedish Natural Science Research Council to H.W.G. and L.J.T Additional financial support was given by the Environment and Climate program of the European commission (MICOR project) to L.J.T. and by the Royal Physiographic Society in Lund. We thank 3 anonymous reviewers for constructive suggestions.

\section{LITERATURE CITED}

Armstrong FAJ, Williams PM, Strickland JDH (1966) Photoaxidation of organic matter in sea water by ultraviolet radiation, analytical and other applications. Nature 211 . $481-483$

Bailey CA, Neihof RA, Tabor PS (1983) Inhibitory effect of solar radiation on amino acid uptake in bacteria in the Chesapeake Bay bacteria. Appl Environ Microbiol 46:44-49

Cooper WJ, Zika RG, Petasne RG, Fischer AM (1989) Sunlight induced photochemistry of humic substances in natural waters: major reactive species. Adv Chem Ser 219:333-362

Ekelund NGA (1993) The effect of UV-B radiation and humic substances on growth and motility of the flagellate Euglena gracilis. J Plankton Res 15:715-722

Fry JC (1988) Determination of biomass. In: Austin B (ed) Methods in aquatic bacteriology. J Wiley \& Sons Ltd, New York, p 27-72

Granéli W, Lindell MJ, Tranvik LJ (1996) Photooxidative $\mathrm{CO}_{2}$ production in lakes of different humic content. Limnol Oceanogr 41(4):698-706

Helbling EW, Villafane V, Ferrario M, Holm-Hansen O (1992) Impact of natural ultraviolet radiation on rates of photosynthesis and on specific marine phytoplankton species. Mar Ecol Prog Ser 89:89-100

Herndl GJ, Müller-Niklas G, Frick J (1993) Major role of ultra-

Responsible Subject Editor: J. Fuhrman, Los Angeles, California, USA
violet-B in controlling bacterioplankton growth in the surface layer of the ocean. Nature 361:717-719

Hessen DO (1985) The relation between bacterial carbon and dissolved humic compounds in oligotrophic lakes. FEMS Microbiol Ecol 31:215-223

Il'In NP, Orlov DS (1973) Photochemical destruction of humic acids. Pochvovedentye 1:73-81

Karentz D, and others (1994) Impact of UV-B radiation on pelagic freshwater ecosystems: report on working group of bacteria and phytoplankton. Arch Hydrobiol Beih Ergeb Limnol 43:31-69

Kieber DJ, McDaniel J, Mopper K (1989) Photochemical source of biological substrates in sea water: implications for the carbon cycling. Nature 341:637-639

Lindell MJ, Granéli W, Tranvik LJ (1995) Enhanced bacterial growth in response to photochemical transformation of dissolved organic matter. Limnol Oceanogr 40:195-199

Mopper K, Stahovec WL (1986) Sources and sinks of low molecular weight organic carbonyl compounds in seawater Mar Chem 19:305-321

Mopper K, Zhou X, Kieber RJ, Kieber DJ, Sikorsky RJ, Jones RD (1991) Photochemical degradation of dissolved organic carbon and its impact on the oceanic carbon cycle. Nature 353:60-62

Muller-Niklas G, Heissenberger A, Puskaric S, Herndl GJ (1995) Ultraviolet-B radiation and bacterial metabolism in coastal waters. Aquat Microb Ecol 9:111-116

Porter KG, Feig YS (1980) The use of DAPI for identifying and counting aquatic microflora. Limnol Oceanogr 25: $943-948$

Scully NM, Lean DRS (1994) The attenuation of ultraviolet radiation in temperate lakes. Arch Hydrobiol Beih Ergeb Limnol 43:135-144

Sieracki ME, Sieburth JM (1986) Sunlight-induced growth delay of marine bacteria in filtered seawater Mar Ecol Prog Ser 33:19-27

Smith DC, Azam F (1992) A simple economical method for measuring bacterial protein synthesis rates in sea water using ${ }^{3} \mathrm{H}$-leucine. Mar Microb Food Webs 6:107-114

Suttle CA, Chen F (1992) Mechanism and decay of marine viruses in seawater. Appl Environ Microbiol 58:105-112

Tranvik LJ (1988) Availability of dıssolved organic carbon for planktonic bacteria in oligotrophic lakes of different humic content. Microb Ecol 16:311-322

Wetzel RG (1990) Land-water interfaces: metabolıc and limnological regulators. Verh Int Verein Theor Angew Limnol $24: 6-24$

Manuscript first received: January 22, 1996

Revised version accepted: July 22, 1996 